\title{
I LLUSTRATIONS
}

\section{Plates}

1 A nineteenth-century portrait of Louis

2 Louis is presented with a copy of Giles of Paris's Karolinus (Karolinus, Bibliothèque nationale de France, MS Latin 6191, fol. $7 \mathrm{v}$.)

3 Louis and King John at La-Roche-aux-Moines (British Library, MS Royal 16 G VI, fol. 385r.)

4 Replica mail constructed according to a thirteenth-century pattern (James Mears)

5 Louis arrives in England (Matthew Paris's Chronica Majora, Parker Library, MS CCCC 16II, fol.50v. Reproduced by kind permission of the Master and Fellows, Corpus Christi College Cambridge)

6 Dover Castle (Julian Humphrys)

7 North wall of Dover Castle (Julian Humphrys)

8 Odiham Castle (Sam Wilson)

9 A charter issued by Louis in 1216 while he was in England (C) The British Library Board, Harley Charter 43 B 37)

10 Guédelon Castle (James Mears)

11 The battle of Lincoln, 1217 (Matthew Paris's Chronica Majora, Parker Library, MS CCCC 16II, fol. 55v. Reproduced by kind 
permission of the Master and Fellows, Corpus Christi College Cambridge)

12 The battle of Sandwich, 1217 (Matthew Paris's Chronica Majora, Parker Library, MS CCCC 16II, fol. 56r. Reproduced by kind permission of the Master and Fellows, Corpus Christi College Cambridge)

13 Louis and Blanche are crowned king and queen of France (Chroniques de France ou de St Denis, British Library, MS Royal 16 G VI, fol. 386v.)

14 Louis's seal as king of France (Archives nationales, Paris)

15 A French silver denier of Louis VIII (James Mears)

16 Louis at the siege of La Rochelle, 1224 (Chroniques de France ou de St Denis, British Library, MS Royal 16 G VI, fol. 388r.)

17 Louis's testament of 1225 (Archives nationales, Paris)

18 The medieval bridge across the river Rhône at Avignon (Pixabay)

19 Louis receives the submission of Avignon (Grandes Chroniques de France, Gallica/Bibliothèque nationale, MS Français 2813, fol. 266v.)

20 Events of 1226, including Louis on his deathbed (Grandes Chroniques de France enluminées par Jean Fouquet, Bibliothèque nationale, MS Français 6465, fol. 251v.)

21 Drawing of Louis's exhumed corpse by Alexandre Lenoir (Musée du Louvre, RF5282-14)

22 The plaque in the crypt at St Denis bearing Louis's name (Beth Spacey)

\section{Maps}

1 England in the thirteenth century

pages

2 France in the thirteenth century

\section{Tables}

1 The Capetians

pages

xiii

2 The Plantagenets

xiv $-\mathrm{xV}$ 